\title{
A BEHAVIORAL ANALYSIS OF PRIVATE JUDGING
}

\author{
CHRISTOPHER R. DRAHOZAL*
}

\section{INTRODUCTION}

A commonly cited reason that businesses include arbitration clauses in their contracts with consumers is to avoid jury trials. ${ }^{1}$ From the perspective of businesses, replacing a jury with an arbitrator "provides much-needed protection from the unpredictability of jury awards, which, in recent years, have been known to reach astronomical heights-awards that appear inappropriate even to the most objective observer." "From the perspective of consumer advocates, businesses choose arbitration to "decrease their likely payout" by avoiding juries, which they believe "will often be sympathetic to the claims of a consumer against a large company." " Underlying these competing perspectives are differing views of jury and arbitral decisionmaking. From the business perspective, juries make awards that are "too high" and thus overcompensate consumer claimants. From the consumer advocates' perspective, arbitrators make awards that are "too low" and thus undercompensate consumer claimants.

Stated otherwise, a central issue in the debate over predispute consumer arbitration clauses is whether juries or arbitrators make "better" decisions-

\section{Copyright (c) 2004 by Christopher R. Drahozal}

This Article is also available at http://www.law.duke.edu/journals/67LCPDrahozal.

* Professor of Law, University of Kansas School of Law.

I appreciate helpful comments from Lee Fennell, Chris Guthrie, Laura Hines, Stephanie Keer, Richard Naimark, Amy Schmitz, Ellen Sward, and Steve Ware, as well as from Symposium participants, especially Tom Metzloff and my discussant, Neil Vidmar.

1. E.g., Jean R. Sternlight, Panacea or Corporate Tool?: Debunking the Supreme Court's Preference for Binding Arbitration, 74 WASH. U. L.Q. 637, 684 (1996) ("One of the company's chief goals in selecting arbitration over litigation is generally to avoid a jury trial."). There are, of course, a number of other reasons businesses might include predispute arbitration clauses in their standard-form contracts, such as confidentiality, reduced availability of class relief, and so on.

2. Martin J. Oppenheimer \& Cameron Johnson, A Management Perspective: Mandatory Arbitration Agreements Are an Effective Alternative to Employment Litigation, DISP. RESOL. MAG., Fall 1997, at 19; see Alan S. Kaplinsky \& Mark J. Levin, Alternative to Litigation Attracting Consumer Financial Services Companies, in ARBITRATION OF CONSUMER FINANCIAL SERVICES DisPUTES 845-48 (Alan S. Kaplinsky ed., 1999) (stating that arbitration "eliminates irrational jury verdicts").

3. Sternlight, supra note 1, at 684; see Margot Saunders, The Increase in Predatory Lending and Appropriate Remedial Actions, 6 N.C. BANKING INST. 111, 137 (2002) ("Creditors use arbitration clauses as a shield to prevent homeowners from litigating their claims in a judicial forum, where a consumer friendly jury might be deciding the case."); David S. Schwartz, Enforcing Small Print to Protect Big Business: Employee and Consumer Rights Claims in an Age of Compelled Arbitration, 1997 WIS. L. REV. 33, 60 (arguing that businesses "prefer arbitration to litigation for their patterned, repetitive disputes with minor players" because of "[l]ower damage awards" in arbitration). 
that is, which decisionmaker more accurately assigns liability and awards damages given the facts of a case and the governing legal standards. This issue is necessarily a comparative one, as no legal decisionmaker is infallible. ${ }^{4}$ A full comparison of jury and arbitral decisionmaking is well beyond the scope of this Article. Instead, this Article focuses on an aspect of arbitral decisionmaking that has been largely unexamined: the extent to which decisionmaking by arbitrators is affected by heuristics ("rules of thumb") and cognitive biases.

Much attention has been given to how such "cognitive illusions" affect decisionmaking by juries. The experimental results have been summarized as follows:

Decades of research on juries indicates that cognitive illusions adversely affect the quality of adjudication. Researchers have found, for example, that juries believe that litigants should have predicted events that no one could have predicted, allow irrelevant or inadmissible information to influence liability determinations, defer to arbitrary numerical estimates, and rely on incoherent methods to calculate damages. ${ }^{6}$

Less, albeit increasing, attention has been given to how cognitive illusions affect decisionmaking by judges. The experimental studies to date, while mixed, have found that judges are less affected by some cognitive illusions, but similarly affected by others.?

Almost no attention, however, has been given to how cognitive illusions might affect arbitral decisionmaking. ${ }^{8}$ This Article extends the behavioral

4. See Robert MacCoun, Inside the Black Box: What Empirical Research Tells Us About Decisionmaking by Civil Juries, in VERDICT: ASSESSING THE CIVIL JURY SYSTEM 164 (Robert E. Litan ed., 1993) ("Several legal scholars have pointed out that the appropriate standard by which to evaluate the quality of jury performance is not some absolute benchmark of perfection, but rather the performance of the most likely alternative factfinder, the trial judge. Or, to extend the argument, the arbitrator, or the expert tribunal.").

5. See generally HEURISTICS AND BIASES: THE PSYCHOLOGY OF INTUITIVE JUDGEMENT (Thomas Gilovich et al. eds., 2002); JUDGMENT UNDER UNCERTAINTY: HEURISTICS AND BIASES (Daniel Kahneman et al. eds., 1982); Amos Tversky \& Daniel Kahneman, Judgment Under Uncertainty: Heuristics and Biases, 185 SCIENCE 1124 (1974). For overviews of the literature from a legal perspective, see, for example, BEHAVIORAl LAW AND ECONOMICS (Cass R. Sunstein ed., 2000); Christine Jolls et al., A Behavioral Approach to Law and Economics, 50 STAN. L. REV. 1471 (1998); Russell B. Korobkin \& Thomas S. Ulen, Law and Behavioral Science: Removing the Rationality Assumption from Law and Economics, 88 CAL. L. REV. 1051 (2000); Donald C. Langevoort, Behavioral Theories of Judgment and Decision Making in Legal Scholarship: A Literature Review, 51 VAND. L. REV. 1499 (1998); Cass R. Sunstein, Behavioral Law and Economics: A Progress Report, 1 AM. L. \& ECON. REV. 115 (1999). For a cautionary view, see Gregory Mitchell, Taking Behavioralism Too Seriously? The Unwarranted Pessimism of the New Behavioral Analysis of Law, 43 WM. \& MARY L. REV. 1907 (2002) [hereinafter Mitchell, Taking Behavioralism Too Seriously?]; Gregory Mitchell, Why Law and Economics' Perfect Rationality Should Not Be Traded for Behavioral Law and Economics' Equal Incompetence, 91 GEO. L.J. 67 (2002) [hereinafter Mitchell, Equal Incompetence].

6. Chris Guthrie et al., Inside the Judicial Mind, 86 CORNELL L. REV. 777, 780-81 (2001).

7. See infra Part III.B.1.

8. The effect of cognitive illusions on consumer decisionmaking has been cited as a possible justification for increased regulation of predispute arbitration clauses in standard-form contracts. Sarah Rudolph Cole, Incentives and Arbitration: The Case Against Enforcement of Executory Arbitration Agreements Between Employers and Employees, 64 U. Mo. K.C. L. REV 449, 482 (1996); Sternlight, supra note 1, at 692-93. A central question is the extent to which market forces may protect consumers who, for whatever reason-cognitive illusions, high information costs, and so forth-do not protect themselves. Christopher R. Drahozal, "Unfair" Arbitration Clauses, 2001 U. ILL. L. REV. 695, 765-66. The mere presence of an arbitration clause in a consumer contract does not necessarily mean that the business drafting the contract 
analysis of the legal system ${ }^{9}$ to private judging, and considers the implications of that analysis for the debate on predispute consumer arbitration clauses. Empirical evidence on the effect of cognitive illusions in arbitral decisionmaking is extremely limited. Further complicating the analysis of private judging are structural differences between arbitration hearings and jury trials that may heighten or dampen the effect of cognitive illusions on decisionmaking in the real world. Nevertheless, assuming arbitrators are more like judges than jurors in their decisionmaking - a seemingly reasonable assumption - studies comparing the effect of cognitive illusions on judges and jurors provide at least a starting point for making predictions about arbitral decisionmaking. On this view, this Article tentatively concludes that, like judges, arbitrators may be less susceptible to at least some cognitive illusions than are jurors.

If subsequent research bears out this tentative conclusion, it would have important implications for the ongoing debate over consumer arbitration. If arbitral decisionmaking is less subject to the effects of cognitive illusions than jury decisionmaking, then the use of arbitration may improve the accuracy of dispute resolution, reducing the risk of overcompensation rather than resulting in undercompensation. ${ }^{10}$ This is not to suggest that utilitarian arguments about the nature of legal decisionmaking should be used to override constitutional protections, ${ }^{11}$ or that juries might not serve other functions beyond dispute resolution. ${ }^{12}$ Instead, the point is simply that when Congress and other policymakers consider whether to restrict the enforceability of consumer arbitration agreements, they should not assume that juries necessarily make "better" decisions than arbitrators.

is taking advantage of the consumer. Limitations on consumer decisionmaking, such as cognitive biases and the use of heuristics, while certainly one consideration in evaluating whether the use of arbitration benefits or harms consumers, are by no means the only one. One often overlooked consideration is the extent to which business reputation and similar market sanctions may counteract the take-it-or-leave-it nature of many consumer form contracts. Id. at 767-69; see RICHARD CRASWELL \& ALAN SCHWARTZ, FOUNDATIONS OF CONTRACT LAW 322-23 (1994) ("Sellers who use unreasonable terms get a reputation for having undesirable contracts.").

9. See Jeffrey J. Rachlinski, The "New" Law and Psychology: A Reply to Critics, Skeptics, and Cautious Supporters, 85 CORNELL L. REV. 739, 739 (2000) (noting that the field is variously referred to as "the psychology of judgment and decision-making," "behavioral economics," and "behavioral decision theory").

10. Even if arbitral decisionmaking is comparable only to jury decisionmaking, this would indicate that some criticisms of consumer arbitration are overstated.

11. See Sternlight, supra note 1, at 733 ("Whatever the arguable benefits of binding arbitration over litigation, our Constitution states that jury trials are to be preferred over arbitration."). For discussions of jury-trial rights and arbitration, see id. at 671; Jean R. Sternlight, Mandatory Binding Arbitration and the Demise of the Seventh Amendment Right to a Jury Trial, 16 OHIO ST. J. ON DISP. RESOL. 669 (2001) [hereinafter Sternlight, Mandatory Binding Arbitration]; Jean R. Sternlight, Rethinking the Constitutionality of the Supreme Court's Preference for Binding Arbitration: A Fresh Assessment of Jury Trial, Separation of Powers, and Due Process Concerns, 72 TUL. L. REV. 1, 76-78 (1997).

12. E.g., Ellen E. Sward, The Decline OF THE Civil JuRY 51-64 (2001) (discussing the political and socializing roles of juries); VALERIE P. HANS \& NEIL VIDMAR, JUDGING THE JURY 249 (1986) (" $[\mathrm{P}]$ olitical functions of the jury are not to be ignored. They coexist with the fact-finding functions and should be considered in judging the jury's role in society."). 
Part II provides an overview of cognitive illusions relevant to decisionmaking by judges, jurors, and arbitrators. Part III summarizes empirical studies that shed light on the effect of cognitive illusions on arbitral decisionmaking. Part IV examines structural differences between jury decisionmaking and arbitral decisionmaking that may increase or decrease the effect of cognitive illusions. Part V concludes with a call for more research.

\section{II \\ HEURISTICS AND COGNITIVE BIASES: AN OVERVIEW AND APPLICATION TO JURORS}

Experimental studies suggest a number of ways in which human behavior systematically departs from a rational-actor model. This Part describes several such "cognitive illusions"-hindsight bias, anchoring, the representativeness heuristic, and extremeness aversion-and examines their application to legal decisionmaking, particularly by jurors..$^{13}$ Certainly there is reason to be cautious about applying laboratory results to real-world settings. But given how juries are selected and jurors' freedom from market incentives, if any legal decisionmaker is susceptible to cognitive illusions, the jury seems the most likely, even taking into account institutional devices for lessening their influence.

\section{A. An Overview of Heuristics and Cognitive Biases}

\section{Hindsight Bias}

"Hindsight is 20/20," the saying goes. Once people know that an event has occurred, it is extremely difficult for them to ignore that occurrence when evaluating the probability that the event would occur in the first place. ${ }^{14}$ As Baruch Fischhoff explains:

In hindsight, people consistently exaggerate what could have been anticipated in foresight. They not only tend to view what has happened as having been inevitable but also to view it as having appeared "relatively inevitable" before it happened. People believe that others should have been able to anticipate events much better than was actually the case. They even misremember their own predictions so as to exaggerate in hindsight what they knew in foresight....

13. Cognitive biases are psychological "biases and aversions that can lead [people] to inaccurate perceptions of facts." Sunstein, supra note 5, at 135. Heuristics are "mental shortcuts" that are often useful but sometimes result in mistaken decisions. See Jeffrey J. Rachlinski, The Uncertain Psychological Case for Paternalism, 97 Nw. U. L. REV. 1165, 1165 (2003); Sunstein, supra note 5, at 139 ("Heuristics are not biases, and often they are good, because they economize on decision costs; but they can lead to several mistakes."). I use the phrase "cognitive illusions" to refer collectively to cognitive biases and heuristics.

14. E.g., Guthrie et al., supra note 6, at 799-801; Jolls et al., supra note 5, at 1523-27; Jeffrey J. Rachlinski, A Positive Psychological Theory of Judging in Hindsight, 65 U. CHI. L. REV. 571, 576 (1998).

15. Baruch Fischhoff, For Those Condemned to Study the Past: Heuristics and Biases in Hindsight, in JUDGMENT UNDER UNCERTAINTY, supra note 5, at 335, 341. 
Of course, not all uses of hindsight in decisionmaking are inappropriate. ${ }^{16}$ If people learn by experience, one would expect them to increase their estimates of the probability of future events based on past events. Moreover, "the fact that something happened provides some information about the risky behavior." "Hindsight bias" occurs when the influence of hindsight on judgment exceeds that which is justifiable.

Experimental studies have found hindsight bias in a variety of decisionmaking settings. ${ }^{18}$ For example, Kim A. Kamin and Jeffrey J. Rachlinski administered a problem based on the well-known tort case of In Re Kinsman Transit Co $^{19}$ to a group of experimental subjects. ${ }^{20}$ In Kamin and Rachlinski's study, subjects in the "foresight condition" were asked to determine whether the risk of a flood was such that the city should hire a bridge operator during winter months when the drawbridge was not used. Subjects in the "hindsight" condition were told that hiring a bridge operator could have prevented debris from becoming lodged under the bridge and causing a flood. Both were asked to decide whether the city should have hired a bridge operator. ${ }^{21}$ Only $24 \%$ of the subjects in the foresight condition required the city to hire a bridge operator, while $57 \%$ of the subjects in the hindsight condition held the city liable for failing to hire a bridge operator. ${ }^{22}$ Kamin and Rachlinski concluded that "outcome knowledge deeply affected participants' interpretations of a complex story." ${ }^{23}$ Moreover, attempts to ameliorate hindsight bias by use of mock jury instructions were unsuccessful. ${ }^{24}$

16. See Mark Kelman et al., Decomposing Hindsight Bias, 16 J. RISK \& UnCERTAINTY 251, 252 (1998) (distinguishing among primary, secondary, and tertiary hindsight bias).

17. Sunstein, supra note 5, at 138.

18. See, e.g., Susan J. LaBine \& Gary LaBine, Determinations of Negligence and the Hindsight Bias, 20 LAW \& HUM. BEHAV. 501, 511 (1996) (reporting that hindsight bias affected mock jurors' "ratings of the foreseeability of violence" and their "opinions of how well therapists fulfilled their duty"); see also Rachlinski, supra note 14, at 576-81 (listing studies). For a critical view, see Jay J.J. ChristensenSzalanski \& Cynthia Fobian Willham, The Hindsight Bias: A Meta-Analysis, 48 ORG'L BEHAV. \& HuM. DECISION PROCESSES 147, 162 (1991) ("The results of this meta-analysis revealed that the overall effect size ... of the hindsight bias is not large."); Mitchell, Taking Behavioralism Too Seriously?, supra note 5, at 1963 (" $[\mathrm{H}]$ indsight bias is not necessarily the juggernaut that Professor Rachlinski and other legal decision theorists portray it to be.").

19. 338 F.2d 708 (2d Cir. 1964).

20. Kim A. Kamin \& Jeffrey J. Rachlinski, Ex Post $\bullet$ Ex Ante: Determining Liability in Hindsight, 19 LAW \& HUM. BEHAV. 89 (1995).

21. Id. at 93-94. Of those subjects in the hindsight condition, some also received jury instructions that sought to reduce the effect of hindsight bias. Id.

22. Id. at 98 .

23. $I d$. at 99 .

24. See id. at 98. Indeed, according to Jeff Rachlinski, "the psychological research demonstrates that the hindsight bias is an extremely robust phenomenon," and attempts to ameliorate the bias through various "debiasing" techniques have proven only partially successful at best. See Rachlinski, supra note 14, at 586-88. But see Philip G. Peters, Jr., Hindsight Bias and Tort Liability: Avoiding Premature Conclusions, 31 ARIZ. ST. L.J. 1277, 1299-1313 (1999) (arguing that "use of several [debiasing strategies] has the potential to reduce the [hindsight] bias enough to raise serious questions about the wisdom of adopting reforms that could significantly favor defendants"); Merrie Jo Stallard \& Debra L. Worthington, Reducing the Hindsight Bias Utilizing Attorney Closing Arguments, 22 LAW \& HUM. BEHAV. 671, 682 (1998) ("[T]he 
The significance of hindsight bias for legal decisionmaking is obvious: In any number of contexts, juries and other legal decisionmakers are required to evaluate conduct in retrospect and estimate the likelihood that an uncertain event would occur. Examples include determinations of whether a party was negligent, whether conduct was reasonable, and whether a contractual contingency was foreseeable.

\section{Anchoring}

In estimating a numerical amount, people tend to start with some initial value-an "anchor" - and then come up with a final estimate by making adjustments to the anchor. If the anchor provides useful information about the underlying value (such as the list price), and if people make reasonable adjustments, this "anchor and adjustment" heuristic can be a useful decisionmaking approach. But anchoring can be problematic if people start with an irrelevant anchor or fail to make adequate adjustments to the initial value. ${ }^{26}$ For example, in one study, Amos Tversky and Daniel Kahneman asked subjects to estimate various percentages, such as the percentage of countries in the United Nations that are African. The starting point for the estimates was a number from one to 100 spun on a "wheel of fortune"-an obviously irrelevant number. The subjects were then asked to state whether the correct number was higher or lower and by how much. The median estimate by subjects given ten as the starting number was that $25 \%$ of the countries in the United Nations were African; the median estimate by subjects given sixty-five as the starting number was $45 \%{ }^{27}$

A number of studies have found that the amount of damages claimed by the plaintiff serves as an anchor for verdicts rendered by mock juries. ${ }^{28}$ Gretchen B.

use of a debiasing strategy [in defense attorneys' arguments] significantly reduced the number of subjects who believed the defendants were negligent.").

25. Rachlinski, supra note 14, at 593 ("Good faith assessments of what constitutes a reasonable course of action in foresight can easily be judged unreasonable in hindsight. Although the hindsight bias also might affect judgments of subjective knowledge or foreseeability, these theories lack empirical support.... [I]t seems likely that the bias does affect these two types of judgments, however.").

26. See, e.g., Guthrie et al., supra note 6, at 787-90; Korobkin \& Ulen, supra note 5, at 1100-02; Sunstein, supra note 5, at 141; see also Cass R. Sunstein, Hazardous Heuristics, 70 U. CHI. L. REV. 751, 762 (2003) ("The most sensible conclusion is that whenever people are uncertain about appropriate values, anchors have a significant effect, and sometimes a startlingly large one.").

27. Tversky \& Kahneman, supra note 5, at 1128.

28. Reid Hastie et al., Juror Judgments in Civil Cases: Effects of Plaintiff's Requests and Plaintiff's Identity on Punitive Damage Awards, 23 LAW \& HUM. BEHAV. 445, 463 (1999) ("We observed a large effect of the plaintiff's award request.... [T] he more the plaintiffs requested, the more they got. The difference in median awards between the Low Anchor (\$15-50 million) and High Anchor (\$50-150 million) conditions was $\$ 35$ million for an identical fact situation. The judge's instructions that these arguments by the attorneys were not evidence did not eliminate this dramatic effect."); John Malouff \& Nicola S. Schutte, Shaping Juror Attitudes: Effects of Requesting Different Damage Amounts in Personal Injury Trials, 129 J. SOC. PSYCHOL. 491, 495 (1989) ("The primary finding of the present experiment was that when more money was requested by the plaintiff's attorney, the jurors awarded more."); Allan Raitz et al., Determining Damages: The Influence of Expert Testimony on Jurors' Decision Making, 14 LAW \& HuM. BEHAV. 385, 393 (1990) ("There is also evidence that jurors in the no expert condition may have 'anchored' on a figure presented at trial."); W. Kip Viscusi, The Challenge of Punitive Damages Mathematics, 30 J. LEGAL STUD. 313, 329 (2001) (finding that "[r]espondents, in effect, abandon the constraints imposed by the deterrence value table and base their judgments [of the appropriate punitive damages 
Chapman and Brian H. Bornstein studied the effect of plaintiff demands on mock jury verdicts and found that (1) "the amount requested ... serves as an anchor that affects compensation awards," and (2) "this effect is linear, even with the extreme amounts used in [the] study," which ranged from $\$ 100$ to $\$ 1$ billion. ${ }^{29}$ The title of their study summarizes their findings: The More You Ask For, the More You Get..$^{30}$ To the extent irrelevant numbers involved in the litigation process alter the damages awarded by juries (and judges and arbitrators as well), awards may be higher or lower than is appropriate.

\section{The Representativeness Heuristic}

People tend to predict the likelihood that an event or person falls within a certain category based on whether the characteristics of the event or person seem representative of the category. This "representativeness heuristic" can be useful, but it can also lead to mistakes when people rely too heavily on the characteristic and too little on the rate at which a characteristic occurs in the underlying population (the "base rate"). ${ }^{31}$ In one study, for example, Tversky and Kahneman described to subjects a woman who had been a philosophy major in college and "was deeply concerned with issues of discrimination and social justice, and also participated in anti-nuclear demonstrations." ${ }^{32}$ When asked whether it was more likely the woman was a bank teller or a bank teller involved in the feminist movement, almost $90 \%$ of the subjects chose the latter. But logically, the class of bank tellers includes the class of feminist bank tellers, such that necessarily the woman is more likely to be a bank teller than a feminist bank teller. The subjects failed to consider the base rate, instead putting too much weight on characteristics that appeared representative of the smaller class. ${ }^{33}$

amount] largely on the anchoring influence" of the amount requested by the plaintiff). As another example, studies have found that statutory damages caps served as anchors for awards of compensatory and punitive damages. See Verlin B. Hinsz \& Kristin E. Indahl, Assimilation to Anchors for Damage Awards in a Mock Civil Trial, 25 J. APPLIED SOC. PSYCHOL. 991, 1016 (1995) (finding that damage awards tend toward damages limits); Jennifer K. Robbennolt \& Christina A. Studebaker, Anchoring in the Courtroom: The Effects of Caps on Punitive Damages, 23 LAW \& HuM. BEHAV. 353, 361, 366 (1999) (finding that high caps resulted in higher damages).

29. Gretchen B. Chapman \& Brian H. Bornstein, The More You Ask For, the More You Get: Anchoring in Personal Injury Verdicts, 10 APPLIED COGNITIVE PSYCHOL. 519, 526-27 (1996).

30. Id.

31. See, e.g., Guthrie et al., supra note 6, at 805-08; Korobkin \& Ulen, supra note 5, at 1085-87.

32. See Amos Tversky \& Daniel Kahneman, Judgments of and by Representativeness, in JUDGMENT UNDER UNCERTAINTY, supra note 5, at 84, 92-93. For a discussion of criticisms of the "Linda problem" (so called because of the name given to the woman by Tversky and Kahneman), see Keith E. Stanovich \& Richard F. West, Individual Differences in Reasoning: Implications for the Rationality Debate?, in HEURISTICS AND BIASES, supra note 5, at 421, 433-34. For a skeptical view, see Gerd Gigerenzer, How to Make Cognitive Illusions Disappear: Beyond "Heuristics and Biases," 2 EUR. REV. SOC. PSYCHOL. 83, 90101 (1991).

33. A related heuristic is availability, in which people tend to disregard base rates and place too much weight on memorable events. E.g., Tversky \& Kahneman, supra note 5, at 1127-28. Jolls et al. cite "anecdote-driven environmental legislation" as an example, explaining that the availability heuristic "encourages the well-known 'pollutant of the month' syndrome, in which regulation is driven by recent and memorable instances of harm." Jolls et al., supra note 5, at 1518. Some supporters of increased regulation of consumer and employment arbitration have sought to take advantage of this heuristic, citing anecdotal 
In the context of legal decisionmaking, commentators have relied on the representativeness heuristic to justify rules of evidence, such as the inadmissibility of character evidence. ${ }^{34}$ The fear is that jurors will disregard the relevant base rate and instead place too much weight on the evidence of bad character..$^{35}$

\section{Extremeness Aversion}

Individuals may seek to avoid extreme results. Experimental studies have found that adding an extreme third option alters the choices subjects make between two other options, even if the third option provides no relevant information about the other two choices. ${ }^{36}$ For example, in a study by Itamar Simonson and Tversky, subjects who had been asked to choose between two cameras, one costing \$169.99 and one costing \$239.99, were evenly split between the two. A third option was then added: a camera costing $\$ 469.99$. With the camera costing \$239.99 now the intermediate option, the percentage of subjects choosing it increased, even though there was an additional choice available. ${ }^{37}$

According to Cass Sunstein, such "[e]xtremeness aversion gives rise to compromise effects. As between given alternatives, most people seek a compromise." ${ }^{\prime 3}$ The implications of extremeness aversion for the legal system are straightforward: to the extent legal decisionmakers have an aversion to extreme outcomes, "[o]ther things being equal, juries and judges may well try to choose a compromise solution." ${ }^{39}$

\section{B. Application to Real-World Jurors}

As this discussion illustrates, behavioral studies of legal decisionmaking raise serious questions about the accuracy of decisionmaking by jurors. Indeed, these studies have prompted some commentators to suggest the possibility of reducing the role of juries in the civil justice system. ${ }^{40}$ An important caveat, however, is that the extent to which the results of experimental studies using

instances of allegedly abusive arbitration practices as evidence of the need for new legislation. E.g., Senator Russell D. Feingold, Mandatory Arbitration: What Process is Due?, 39 HARV. J. ON LEGIS., 281, 281 (2002).

34. FED. R. EVID. 404(a).

35. Korobkin \& Ulen, supra note 5, at 1087-88.

36. E.g., Schlomo Benartzi \& Richard H. Thaler, How Much Is Investor Autonomy Worth?, 57 J. Fin. 1593,1610 (2002) ("Consistent with extremeness aversion, [a given investment program] is the least attractive when framed as an extreme choice and most attractive when framed as the middle choice."); Mark Kelman et al., Context-Dependence in Legal Decision Making, 25 J. LEGAL STUD. 287, 290-95 (1996) (reporting that subjects were more likely to choose a verdict of murder over manslaughter when murder was intermediate option).

37. Itamar Simonson \& Amos Tversky, Choice in Context: Tradeoff Contrast and Extremeness Aversion, 29 J. MARKETING RES. 281, 290 (1992).

38. Sunstein, supra note 5, at 135. Extremeness aversion is a form of context dependence, because the preferences of the subjects vary depending on the context in which the choice is made. Kelman et al., supra note 36 , at 288 .

39. Sunstein, supra note 5 , at 136.

40. See Cass R. Sunstein et al., Predictably Incoherent Judgments, 54 Stan. L. ReV. 1153, 1182-84 (2002); W. Kip Viscusi, How Do Judges Think About Risk?, 1 AM. L. \& ECON. REV. 26, 60 (1999). 
mock jurors apply to real-world decisionmaking by jurors cannot be known for certain.

To be sure, some criticisms of experimental studies are not particularly applicable to juries. For example, one reason to doubt the effectiveness of experimental results in predicting real-world outcomes is the effect of selection. As Richard Posner explains:

Selection effects suggest that the experimental and real-world environments will differ systematically. The experimental subjects are chosen more or less randomly; but people are not randomly sorted to jobs and other activities. People who cannot calculate probabilities will either avoid gambling, if they know their cognitive weakness, or, if they do not, will soon be wiped out and thus be forced to discontinue gambling. People who are unusually "fair" will avoid (or, again, be forced out of) roughhouse activities-including highly competitive businesses, trial lawyering, and the academic rat race. Hyperbolic discounters will avoid the financial services industry. These selection effects will not work perfectly, but they are likely to drive a big wedge between experimental and real-world consequences of irrationality. ${ }^{41}$

In contrast, the largely random selection of juries bears substantial similarities to the selection of subjects for experimental studies-indeed, some studies have used as subjects individuals waiting to serve as prospective jurors. ${ }^{42}$ This suggests that the results of experimental studies may be more appropriately applied to jury decisionmaking than many other real-world activities.

On the other hand, it is no doubt true that the vast majority of jurors take their responsibilities more seriously than do participants in experimental studies. As Philip Peters explains:

Unlike research subjects, jurors are accountable for their decisions. Each juror's vote will be scrutinized not only by the other jurors, but also by the judge and often by the juror's family and friends. Jurors also feel accountable to their communities. This accountability distinguishes jury trials from research studies and has the potential to improve jury decision-making.

Moreover, most experimental subjects receive far less information about the case they are asked to decide than real-world jurors, raising questions about the "ecological validity" of the experiments. ${ }^{44}$ Certainly other differences between experimental settings and real-world jury trials likewise have the potential to increase or decrease the effect of cognitive biases on the decisionmaking of jurors. As a result, any conclusions from experimental studies in this area will necessarily have some degree of uncertainty.

41. Richard A. Posner, Rational Choice, Behavioral Economics, and the Law, 50 STAN. L. REV. 1551, 1570-71 (1998).

42. E.g., Neil Vidmar \& Jeffrey J. Rice, Assessments of Noneconomic Damage Awards in Medical Negligence: A Comparison of Jurors with Legal Professionals, 78 IOWA L. REV. 883, 891 (1993).

43. Peters, supra note 24 , at 1300-01. On the importance of accountability (or lack thereof) in experimental studies, see Mitchell, Equal Incompetence, supra note 5, at 110-14; Philip E. Tetlock, Accountability and Complexity of Thought, 45 J. PERSONALITY \& SOC. PSYCHOL. 74, 74-75 (1983) ("The evidence on the effects of accountability is thus mixed: sometimes accountability leads to complex or effortful information processing, and sometimes it leads to expedient decisions that can be readily justified to others.").

44. See Richard Lempert, Juries, Hindsight, and Punitive Damage Awards: Failures of a Social Science Case for Change, 48 DEPAUl L. REV. 867, 877 (1999); Mitchell, Taking Behavioralism Too Seriously?, supra note 5, at 1985. 
III

\section{Heuristics AND COGNITIVE BIASES IN ARBITRAL DECISIONMAKING}

The effects of cognitive illusions on jury decisionmaking have been studied often, at least in experimental settings. The effects of cognitive biases on other legal decisionmakers, especially arbitrators, have been studied far less. This Part discusses the available evidence on how heuristics and cognitive biases might affect arbitrators. It begins by examining the extremely limited empirical research on cognitive illusions in arbitral decisionmaking. Because that evidence (experimental or otherwise) is so limited, this Part then considers evidence on the effect of cognitive illusions on judicial decisionmaking. The assumption inherent in this comparison is that the effect of cognitive illusions on arbitrators is more like their effect on judges than their effect on jurors. If so, evidence on heuristics and cognitive biases from studies of judicial decisionmaking may provide some insights into arbitral decisionmaking as well.

The existing evidence on judges takes two forms: experimental studies of judicial decisionmaking and studies of litigation outcomes comparing the results of cases decided by judges and those decided by juries. Taken together, these studies suggest that (1) judges are less affected by some cognitive illusions than jurors and equally, but no more, affected by others, and (2) these differences seem to persist in actual cases, although to a lesser degree than might be expected from the experimental studies alone. While far from conclusive, this evidence suggests that arbitrators may be somewhat less subject to cognitive illusions than jurors.

\section{A. Empirical Studies of Arbitral Decisionmaking}

Empirical studies of the prevalence of cognitive illusions in arbitral decisionmaking are exceedingly rare. I am aware of no such studies using experimental techniques. Moreover, arbitration proceedings are private, and most arbitration awards are unpublished. ${ }^{45}$ As a result, studies of outcomes in commercial (including consumer and employment) arbitration are uncommon. ${ }^{46}$

45. Cf. Christopher R. Drahozal, Commercial Norms, Commercial Codes, and International Commercial Arbitration, 33 VAND. J. TRANSNAT'L L. 79, 122 (2000) (discussing international arbitration awards).

46. In addition to the studies discussed in this section, see the studies of employment arbitration outcomes by Lisa B. Bingham. Lisa B. Bingham, Employment Arbitration: The Repeat Player Effect, 1 EMPLOYEE RTS. \& EMP. POL'Y J. 189 (1997) [hereinafter Bingham, The Repeat Player Effect]; Lisa B. Bingham, On Repeat Players, Adhesive Contracts, and the Use of Statistics in Judicial Review of Employment Arbitration Claims, 29 MCGEORGE L. REV. 223 (1998) [hereinafter Bingham, On Repeat Players]; Lisa B. Bingham, Self-Determination in Dispute System Design and Employment Arbitration, 56 U. MIAMI L. REV. 873 (2002) [hereinafter Bingham, Self-Determination]; Lisa B. Bingham, Unequal Bargaining Power: An Alternative Account for the Repeat Player Effect in Employment Arbitration, in INDUSTRIAL RELATIONS RESEARCH ASSOCIATION 50TH ANNUAL PROCEEDINGS 33 (1999) [hereinafter Bingham, Unequal Bargaining Power]; Lisa B. Bingham \& Simon Sarraf, Employment Arbitration Before and After the Due Process Protocol for Mediation and Arbitration of Statutory Disputes Arising Out of Employment: Preliminary Evidence that Self-Regulation Makes a Difference, in ALTERNATIVE DISPUTE RESOLUTION IN THE EMPLOYMENT ARENA: PROCEEDINGS OF NEW YORK UNIVERSITY 53RD ANNUAL CONFERENCE ON LABOR (Samuel Estreicher ed., 2003). 
One area in which some empirical work has been done is in testing whether arbitrators have a tendency to reach compromise awards-to "split the baby." This phenomenon, if it exists, is sometimes credited to the anchoring of awards on the amount sought by the claimant. ${ }^{47}$ Compromise awards would also be consistent with extremeness aversion by arbitrators. Another suggested explanation is that market forces give arbitrators an incentive to compromise, to keep both sides happy and willing to select the arbitrator again. ${ }^{48}$ The implications of arbitral incentives are less clear in the context of consumer and employment arbitration (although behavioral considerations would seem to be the same). Individual consumers and employees are unlikely to be repeat players, so arbitrators have little incentive to reach compromise solutions to induce consumers and employees to select them again. Attorneys for consumers and employees, however, may be repeat players. ${ }^{49}$

Two published studies of commercial arbitration (one domestic and one international) have found no evidence that arbitrators make compromise awards. In her classic study, Soia Mentschikoff examined commercial arbitrations administered by the American Arbitration Association (AAA) between 1947 and $1950 .^{50}$ In $50 \%$ of the awards, the claimant was awarded either all or none of the amount sought. "Obviously," Mentschikoff concluded, "such awards can not be the result of compromise." ${ }^{51}$ In addition, Mentschikoff examined more closely thirty-six additional cases, finding that "many of the partial awards are arrived at in a judicial manner since they result from the striking of particular items of damage that the arbitrators believe are not justified under the facts or law of the particular case.,"52

A recent study of international arbitration awards by Stephanie E. Keer and Richard W. Naimark also rejected the view that arbitrators make compromise awards. ${ }^{53}$ In a sample of fifty-four international arbitration proceedings administered by the AAA, the mean award as a percentage of the amount claimed was $50.53 \%$, and the median award was $46.66 \%$. The distribution of the awards, however, was bimodal, with $31 \%$ of claimants recovering nothing and $35 \%$ recovering $100 \%$ of the amount claimed. The remaining $34 \%$ of claimants

47. Stephanie E. Keer \& Richard W. Naimark, Arbitrators Do Not "Split the Baby"-Empirical Evidence from International Business Arbitration, 18 J. INT”L ARB. 573, 573-74 (2001).

48. Cf. Alan Scott Rau, Integrity in Private Judging, 38 S. TeX. L. REV. 485, 523 (1997) ("The dynamic of arbitrator self-interest has long been familiar in collective bargaining cases and is thought, for example, to provide one explanation for the apparently common practice of compromise awards. Repeat business for the arbitrator is likely only if he is able to retain the future goodwill of both union and management; the desire to do so may give him an incentive (in the hallowed phrase) to 'split the baby."').

49. See Drahozal, supra note 8, at 751; Samuel Estreicher, Predispute Agreements to Arbitrate Statutory Claims, 72 N.Y.U. L. REV. 1344, 1355 (1997). But see Bingham, The Repeat Player Effect, supra note 46, at 198-99 ("[T]here is reason to believe that most individual members of the plaintiffs' bar may never successfully emerge as repeat players in employment arbitration.").

50. Soia Mentschikoff, Commercial Arbitration, 61 CoLUM. L. REV. 846, 856-67 (1961).

51. Id. at 861.

52. Id.

53. Keer \& Naimark, supra note 47. 
were awarded a widely distributed percentage of the amount claimed. ${ }^{54}$ Keer and Naimark concluded that "the results from this study show emphatically that arbitrators do not engage in the practice of 'splitting the baby.", 55 The studies examining the possibility of compromise awards thus have uncovered no evidence of extremeness aversion in arbitral decisionmaking. ${ }^{56}$

Several studies have sought to compare outcomes in arbitration and litigation, but they shed little light on behavioral aspects of arbitral decisionmaking. In one study, Theodore Eisenberg and Elizabeth Hill compared a sample of 261 AAA employment arbitration awards with verdicts in state-court employment cases and employment discrimination cases in federal court. ${ }^{57}$ Relying on the AAA's categorization of the arbitration agreements as either "promulgated" by the company or individually negotiated by the employee, they found that winrates and awards in arbitrations arising under individually negotiated agreements were largely indistinguishable from the outcomes in court cases. They acknowledged, however, that they were unable to control either for "original differences in the merits of the disputes routed to arbitration and litigation" or for differences in settlements, which could undercut the comparability of disputes in arbitration and litigation. ${ }^{58}$

In another study, William Howard compared a sample of arbitration awards dealing with employment discrimination claims to court cases involving alleged employment discrimination..$^{59}$ The mean jury award in the court cases studied was $\$ 417,178$, while the mean arbitration award was $\$ 114,905$. Howard did not attempt to control for differences in the claims, such as the strength of the claim on the merits and the extent of injuries suffered. Thus, at least some of the difference in recovery between court and arbitration likely is due to differences in

54. Id. at 574. Keer and Naimark also describe an unpublished AAA study of 4,479 commercial arbitration awards with results consistent with their findings. Id. at 574 (finding that "approximately $42 \%$ of those cases were awarded $0-20 \%$ of their original claim amount," while " $30 \%$ were awarded $81-100 \%$ of their original claim amount").

55. Id. at 578. Neither study makes any attempt to compare the likelihood of compromise awards in arbitration to the likelihood of compromise judgments or verdicts in civil litigation.

56. An alternative interpretation of these results might be that extremeness aversion applies only to choices among discrete alternatives but not to choices along a continuum, as an arbitrator (or jury) would make in determining the amount of damages to award.

57. Theodore Eisenberg \& Elizabeth Hill, Employment Arbitration and Litigation: An Empirical Comparison, in ALTERNATIVE DISPUTE RESOLUTION IN THE EMPLOYMENT ARENA, supra note 46. For more detailed information on the AAA arbitration awards in the sample, see Elizabeth Hill, Due Process at Low Cost: An Empirical Study of Employment Arbitration Under the Auspices of the American Arbitration Association, 18 OHIO ST. J. ON DISP. RESOL. 777 (2003) [hereinafter Hill, Due Process at Low Cost]; Elizabeth Hill, AAA Employment Arbitration: A Fair Forum at Low Cost, DisP. RESOL. J., May-July 2003, at 9 .

58. Eisenberg \& Hill, supra note 57, at 21-23. Michael Delikat and Morris Kleiner found little difference in outcomes between employment arbitrations involving securities industry employees and employment discrimination cases litigated in federal court. Michael Delikat \& Morris Kleiner, Empirical Study of Securities Industry Arbitration v. Litigation, in ALTERNATIVE DISPUTE RESOLUTION IN THE EMPLOYMENT ARENA, supra note 46. They acknowledge, however, that they lacked data on "additional variables that may control for factors that may influence the outcomes of a trial or private sector adjudication." Id. at 7 .

59. William M. Howard, Arbitrating Claims of Employment Discrimination: What Really Does Happen? What Really Should Happen?, DiSP. RESOL. J., Oct.-Dec. 1995, at 40. 
the claims in the different fora, rather than differences between decisionmakers. ${ }^{60}$

Lewis Maltby compared the results of AAA employment arbitrations from 1993 to 1995 with the results of employment cases litigated in federal courts in 1994. ${ }^{61}$ He recognized that the cases were not comparable on the merits, noting that "[ $\mathrm{t}]$ he district court cases all involved statutory civil rights claims for which the law provides emotional distress and punitive damages" while "[m]any of the AAA cases ... were contract claims with only economic damages." ${ }^{62}$ Maltby sought to control for the differing types of claims by comparing arbitration and litigation on the basis of damages awarded as a percentage of the amount claimed. Under this approach, he found that employees recovered $18 \%$ of amounts claimed in arbitration, but only $10.4 \%$ of amounts claimed in court. ${ }^{63}$

Donald Wittman has compared outcomes in jury cases with outcomes in court-annexed arbitration proceedings. ${ }^{64}$ Examining a sample of 353 cases tried both by an arbitrator and a jury (thus ensuring that the facts of the cases were the same), he found substantial similarities between jury decisionmaking and arbitral decisionmaking. ${ }^{65}$ Unfortunately, the results provide little insight into how arbitration awards in consumer and employment cases (in other words, arbitrations that are not court-annexed) compare to jury verdicts. In Wittman's study, arbitrators had a strong incentive to make an award close to the likely jury verdict in the case, and parties had a strong incentive to select arbitrators whose awards were accurate predictions of jury verdicts. ${ }^{66}$ Parties to predispute arbitration clauses in consumer contracts have no comparable incentive to prefer arbitrators whose awards mirror jury verdicts.

Finally, Neil Vidmar and Jeffrey J. Rice conducted an experimental study that compared the damages awarded by jurors and arbitrators in a hypothetical medical malpractice case. ${ }^{67}$ They gave a description of the case to twenty-one

60. Id. at 45. For further criticisms of Howard's methodology, see Hill, Due Process at Low Cost, supra note 57 , at $788-89$.

61. Lewis Maltby, Private Justice: Employment Arbitration and Civil Rights, in ARBITRATION NOw 1, 16-18 (Paul H. Haagen ed., 1999) [hereinafter Maltby, Private Justice]; see Lewis Maltby, Employment Arbitration: Is It Really Second Class Justice?, DISP. RESOL. MAG., Fall 1999, at 23 [hereinafter Maltby, Second Class Justice]. Maltby used data on employment arbitration awards collected and reported by Lisa Bingham, see infra text accompanying notes 133-34.

62. Maltby, Private Justice, supra note 61, at 17-18.

63. Id. at 18. For an alternative interpretation of Maltby's results, see infra note 143.

64. Donald Wittman, Lay Juries, Professional Arbitrators, and the Arbitrator Selection Hypothesis, 5 AM. L. \& ECON. REV. 61 (2003). Robert MacCoun describes another, unpublished study by Wittman that "compared jury and arbitration awards and found that juries were more variable than arbitrators," possibly due to "forum selection processes." MacCoun, supra note 4, at 164-65.

65. Wittman, supra note 64 , at 80 ("[W]ith the exception of the deep pockets issue, the jury and arbitrator equations are very similar regarding both their coefficients and their sum of squared errors.").

66. Wittman examined court-annexed arbitration conducted under a scheme whereby a party requesting a trial had to pay the arbitrator's fee and other costs if the jury verdict was not more favorable to the party than the arbitration award. $I d$.

67. Vidmar \& Rice, supra note 42; see NeIl VIDMAR, MEdicAl MALPRACTICE AND THE AMERICAN JURY: CONFRONTING THE MythS ABOUT JURY INCOMPETENCE, DEEP POCKETS AND OUTRAGEOUS DAMAGE AWARDS 221-35 (1995). 
lawyers who had served as arbitrators "for various personal injury, contract, and labor disputes," and eighty-nine prospective jurors who actually had been selected for jury duty. ${ }^{68}$ The median and mean damage awards by the two groups were statistically indistinguishable. ${ }^{69}$ The damage awards by the individual jurors, however, had a substantially higher variance (although when the individual awards were pooled into twelve-juror panels, the variance fell substantially).$^{70}$

Overall, the extremely limited empirical evidence on cognitive illusions in arbitral decisionmaking casts little light on how arbitral decisionmaking compares to jury decisionmaking. Arbitrators (at least in commercial cases) do not seem to be subject to extremeness aversion, and there is some experimental evidence that arbitral awards may have a similar mean but less variance than the verdicts of individual jurors. Studies comparing outcomes in litigation and arbitration, while increasingly common, do not focus specifically on cognitive illusions and are subject to serious limitations due to case-selection effects. At present, there is far too little evidence to draw firm conclusions.

\section{B. Empirical Studies Comparing Decisionmaking by Judges and Juries}

Notwithstanding the limited empirical evidence on heuristics and cognitive biases in arbitral decisionmaking, it may be possible to gain some insight into arbitral decisionmaking by examining judicial decisionmaking, a close but by no means exact analogy. Arbitrators, like judges, resolve disputes on a recurring basis. $^{71}$ Jurors' experiences, by contrast, are limited to individual trials. Arbitrators, like judges, receive specialized training; jurors receive only a judge's instructions. Many arbitrators, like judges, are lawyers. ${ }^{72}$ The vast majority of jurors are not. Demographically, too, arbitrators tend to look more like judges than jurors. ${ }^{73}$ The analogy is, of course, only a rough one. Nevertheless, given

68. Vidmar \& Rice, supra note 42 , at $890-91$.

69. Id. at 893 .

70. Id. at 897-98; see also infra Part IV.A. (discussing potential differences between group and individual decisionmaking).

71. See Mitchell, Equal Incompetence, supra note 5, at 153-54 (discussing the potential importance of "feedback and opportunities for learning" in reducing the effect of cognitive illusions).

72. Although lawyers and other professionals are subject to the effects of cognitive biases, some research suggests that they may be less affected than nonprofessionals. See Chris Guthrie, Panacea or Pandora's Box? The Costs of Options in Negotiation, 88 IOWA L. REV. 601, 641 (2003) ("This is not to say, of course, that lawyers are pure 'rational actors' who are impervious to the effects of 'psychological biases' in decisionmaking; in fact, lawyers, like other novice and expert decision-makers, are susceptible to such biases. However, experimental evidence suggests that lawyers are more likely than others to be able to resist these biases and make decisions rationally."). Not all arbitrators are lawyers either. Many arbitrators in trade association arbitrations, for example, are selected for their experience in the industry. See, e.g., Lisa Bernstein, Private Commercial Law in the Cotton Industry: Creating Cooperation Through Rules, Norms, and Institutions, 99 MICH. L. REV. 1724, 1728 (2001). But such experience itself could provide feedback and an opportunity to learn that might improve arbitral decisionmaking relative to juries. See supra note 71.

73. Compare U.S. Gen. ACCOUNTING OFFICE, EMPlOYMENT DiscriminAtion: How REGISTERED REPRESENTATIVES FARE IN DISCRIMINATION DISPUTES 2 (1994), with Amy E. Black \& Stanley Rothman, Shall We Kill All the Lawyers First?: Insider and Outsider Views of the Legal Profession, 21 HARV. J. L. \& PUB. POL'Y 835, 838-42 (1998). 
the lack of studies of how biases and heuristics affect arbitrators, studies comparing their effects on judges and juries may provide some insight. ${ }^{74}$

\section{Experimental Studies}

Only recently have researchers begun conducting experimental studies of cognitive illusions in judicial decisionmaking. Although only a handful of such studies have been published, they have been broader in scope than the studies of arbitral decisionmaking. ${ }^{75}$ To date, the results are somewhat conflicting. Nevertheless, as a general matter, the studies have found judicial decisionmaking to be less affected by cognitive illusions than decisionmaking by juries in some respects, but equally affected in others. ${ }^{76}$

In one study, Chris Guthrie, Jeffrey J. Rachlinski, and Andrew J. Wistrich administered a questionnaire to federal magistrate judges attending a Federal Judicial Center workshop in 1999. ${ }^{77}$ A total of 168 judges returned the questionnaire, with one requesting that the response not be used in further research, leaving a sample of 167. The questionnaire contained a series of hypothetical fact patterns designed to test for the effect of various heuristics and cognitive biases on judicial decisionmaking. Based on the answers to the questionnaire, the authors concluded that judges were less affected by some cognitive illusions than jurors but similarly affected by others. The judges "were impressive" in answering correctly "a difficult [evidentiary] question in a short period of time,"

74. The focus here is on studies that compare decisionmaking by judges and juries, rather than studies that consider one of the two (usually juries) alone. For surveys of empirical research on jury decisionmaking, see Robert J. MacCoun, Experimental Research on Jury Decisionmaking, 244 SCIENCE 1046, 1046-50 (1989); MacCoun, supra note 4, at 137; Neil Vidmar, The Performance of the American Civil Jury: An Empirical Perspective, 40 ARIZ. L. REV. 849 (1998). For a survey of empirical studies focusing on punitive damage awards, see Jennifer Robbennolt, Determining Punitive Damages: Empirical Insights and Implications for Reform, 50 BUFF. L. REV. 103 (2002).

75. In addition, experimental studies have compared hypothetical damage awards of judges and jurors, without explicitly considering cognitive illusions. See, e.g., Stephen Landsman \& Richard F. Rakos, A Preliminary Inquiry into the Effect of Potentially Biasing Information on Judges and Juries in Civil Litigation, 12 BEHAV. SCI. \& L. 113, 125 (1994) ("[J]udges and jurors in civil cases react similarly when exposed to material that is subsequently ruled inadmissible-their perceptions of central trial issues are altered."); Jennifer K. Robbennolt, Punitive Damages Decision Making: The Decisions of Citizens and Trial Court Judges, 26 LAW \& HuM. BEHAV. 315, 333 (2002) ("No differences were found in the likelihood that punitive damages would be awarded or in the sizes of the punitive damages awards of judges and jury-eligible citizens."); Roselle L. Wissler et al., Decisionmaking about General Damages: A Comparison of Jurors, Judges, and Lawyers, 98 MICH. L. REV. 751, 756 (1999) ("[T]he models evidence a remarkable degree of similarity among all groups of decisionmakers, plus a high degree of predictability, in regard to their judgments of injury severity. As to the translation of injury perceptions into monetary awards, however, more differences among the groups appeared, and the predictive power of the models declined.").

76. See Rachlinski, supra note 13, at 1200 ("Although few studies have been conducted on judges, what work has been done suggests that judges are also subject to the same cognitive errors in judgment that affect juries.").

77. Guthrie et al., supra note 6. For a study on hindsight bias using a sample of fifty-eight auditors and sixty-five state and federal trial judges, see John C. Anderson et al., Evaluation of Auditor Decisions: Hindsight Bias Effects and the Expectation Gap, 14 J. ECON. PSYCHOL. 711, 730 (1993) ("[O]ur findings provide new evidence that individuals' evaluations of auditor's performance are dependent on outcome information. Subjects provided higher auditor evaluations in the presence of favorable outcome information and lower evaluations in the presence of unfavorable outcome information."). 
thereby avoiding the representativeness heuristic (although $60 \%$ still answered incorrectly). ${ }^{78}$ However, the results suggested that judges were as susceptible to anchoring effects and hindsight bias as other decisionmakers. ${ }^{79}$ Thus, judges awarded substantially less when the defendant moved to dismiss for failure to satisfy the $\$ 75,000$ amount-in-controversy requirement for federal diversity jurisdiction (which plainly was met on the facts) than when no such motion was filed. In the view of Guthrie et al., "the $\$ 75,000$ jurisdictional minimum anchored their damage awards." ${ }^{80}$ Further, judges' predictions of the likely outcome of a case on appeal were highly sensitive to what they were told about the actual outcome, which, according to Guthrie et al., was an illustration of hindsight bias. ${ }^{81}$

A study by W. Kip Viscusi and Reid Hastie found judges to be less subject to hindsight bias than mock jurors. ${ }^{82}$ The authors distributed a questionnaire to a sample of state-court judges (both trial and appellate) attending a law-andeconomics program. They received ninety-five responses, a response rate of almost $100 \%$. They then administered the same questionnaire to mock jurors, to facilitate comparison. In a pair of tests for hindsight bias, Viscusi and Hastie found that the judges "were much less prone to hindsight bias than are jurors in their treatment of corporate safety decisions. Indeed, in making legal judgments, there was little effect of hindsight for judges, as compared to substantial effects for mock jurors." ${ }^{" 83}$

Several commentators have criticized the sample of judges studied by Viscusi and Hastie. Guthrie et al. assert that the sample and the context "may have induced somewhat more calculated reasoning processes that dampened the effect." ${ }^{" 4}$ Richard Lempert likewise criticizes the sample of judges, asserting that the program "may well have attracted judges who are more pro-business

78. Guthrie et al., supra note 6, at 809-11.

79. Id. at 787-94, 799-805. Unlike the Viscusi and the Hastie and Viscusi studies, see infra text accompanying notes 82-83, Guthrie et al. did not administer a similar questionnaire to mock jurors. Indeed, at least some of the questions they asked required decisions that a jury would not make. See, e.g., id. at 791 (describing an anchoring question requiring magistrate judges to rule on a motion to dismiss for want of subject matter jurisdiction). Instead, Guthrie et al. compared the magnitude of the biases they found to the magnitude found in other studies, based on different fact patterns, id. at 816-18, making it difficult to draw any firm conclusions about comparability. See Mitchell, Taking Behavioralism Too Seriously?, supra note 5, at 1998 n.184.

80. Guthrie et al., supra note 6, at 791-92.

81. Id. at 802-03.

82. Reid Hastie \& W. Kip Viscusi, What Juries Can't Do Well: The Jury's Performance as a Risk Manager, 40 ARIZ. L. REV. 901 (1998); Viscusi, supra note 40. The results of the study were published separately by Viscusi and by Viscusi and Hastie together.

83. Viscusi, supra note 40, at 59; Hastie \& Viscusi, supra note 82, at 917. Viscusi and Hastie also examined risk assessment by judges, concluding that while "judges did exhibit many of the patterns of biases in risk judgments that have been the focus of the literature on the rationality of choice under uncertainty," in general, "these biases do not contaminate the thinking of judges with respect to their interpretation of legal rules." Viscusi, supra note 40, at 60; see also W. Kip Viscusi, Jurors, Judges, and the Mistreatment of Risk by the Courts, 30 J. LEGAL STUD. 107, 135 (2001) (finding that "[j]udges had more accurate risk beliefs and were less prone to overestimate low-probability events" than were jurors).

84. Guthrie et al., supra note 6, at 818 n.201; see also Robbennolt, supra note 75, at 335. 
than judges generally." ${ }^{85}$ Lempert is also critical that the sample included both trial judges and appellate judges because "[t]rial judges, as a group, may have different values or, because their experiences differ, they may respond differently in hindsight." ${ }^{86}$ While perhaps underestimating the susceptibility of judges generally to hindsight bias, at a minimum, the study suggests that some judges are able to avoid this bias. As such, it also suggests that some arbitrators may be able to avoid hindsight bias as well.

\section{Studies of Litigation Outcomes}

While experimental studies are able to control for the underlying facts of the dispute, studies of real-world litigation outcomes avoid charges of lack of realism. $^{87}$ This section examines several studies that compare outcomes (either win rates or damage awards) in cases decided by judges and juries, to see the extent to which experimental differences in judicial versus jury decisionmaking may affect real cases.

The earliest and best-known study seeking to compare outcomes between judges and juries is Harry Kalven and Hans Zeisel's University of Chicago Jury Project. $^{88}$ Kalven and Zeisel collected reports on 4000 civil jury verdicts and then asked each judge "how he would have decided the case had it been tried to him alone." ${ }^{89}$ They found that in $78 \%$ of the cases, the judge agreed with the jury's verdict on liability. In $12 \%$, the jury found for the plaintiff while the judge would have found for the defendant. In the remaining $10 \%$, the jury found for the defendant while the judge would have found for the plaintiff. $^{90}$ Juries, however, awarded significantly higher damages. Of the cases in which the judge agreed with the jury's finding for the plaintiff (44\%), on average the jury-awarded damages were $20 \%$ higher than what the judge would have awarded. ${ }^{91}$ One weakness with the methodology is that the judges were asked whether they agreed with the jury's verdict after it was rendered, rather than being asked before the verdict what they thought the outcome should be. Thus, "it is possible that their responses partially reflected their attitudes toward the jury system in addition to their evaluation of the cases at hand."

85. Lempert, supra note 44, at 884 . For a response, see Reid Hastie \& W. Kip Viscusi, Juries, Hindsight, and Punitive Damages Awards: Reply to Richard Lempert, 51 DEPAUL L. REV. 987 (2002).

86. Lempert, supra note 44 , at 884.

87. See supra Part II.B. Such studies also necessarily control for differences in the structural characteristics of the various dispute-resolution processes, which experimental studies can do only imperfectly at best. See infra Part IV.

88. See Harry Kalven, JR. \& Hans Zeisel, The American Jury 63-64 (1966). The focus of THE AMERICAN JURY, however, is on juries in criminal cases. Id. at 55-81.

89. Harry Kalven, Jr., The Dignity of the Civil Jury, 50 VA. L. REv. 1055, 1063 (1964).

90. KALVEN \& ZEISEL, supra note 88, at 63-64; see also Kalven, supra note 89, at 1065 (reporting $79 \%$ agreement in personal injury cases).

91. KALVEN \& ZEISEL, supra note 88, at 64 n.13; Kalven, supra note 89 at 1065.

92. MacCoun, supra note 4, at 165 . For other criticisms, see Michael H. Walsh, The American Jury: A Reassessment, 79 YALE L.J. 142, 146-47 (1969) (pointing out that the "sample used was not statistically ideal"). 
the advantage, however, of ensuring that the cases evaluated by the jury and the judge were identical.

Other studies of litigation outcomes have been much less able to control for case characteristics. Thus, they are potentially subject to serious selection effects that make interpretation of the results difficult. ${ }^{93}$ For example, in a sample of federal court cases decided between 1979 and 1989, Kevin M. Clermont and Theodore Eisenberg found a number of categories of cases in which plaintiffs had higher win rates before judges than before juries. ${ }^{94}$ They concluded that "the most plausible explanation of the data lies in small differences between judges' and juries' treatment of cases and, more importantly, in the parties' varying the selection of cases that reach judge and jury." ${ }^{95}$ A subsequent study by Eric Helland and Alexander Tabarrok, using a sample of statecourt verdicts, found that "[j]uries do grant systematically larger awards to injured plaintiffs than judges. ${ }^{\prime 96}$ Most of the difference, they found, was due to differential routing of cases to judges and juries:

The differences in judge and jury decision-making we have discovered, however, explain only one-quarter to one-third of the difference in average award rates across judges and juries. Three[-]quarters to two-thirds of the difference in average awards is due not to differences in decision-making but to differences in the sample of cases appearing before judges and juries. ${ }^{97}$

Of course, the same results could be restated with the opposite emphasis: up to one-third of the difference between awards by judges and juries persists even after attempting to control for case-selection effects.

A recent study by Theodore Eisenberg et al. focused on the award of punitive damages by judges and jurors. ${ }^{98}$ They considered a sample of state-court jury trials from forty-five of the seventy-five most populous counties in the United States from 1996, and found that "[j]uries and judges award punitive damages at about the same rate, and their punitive awards bear about the same relation to their compensatory awards." $"$ While they found somewhat greater variance in jury awards, "the effect is not robust and leads to very few jury punitive awards outside the range of what judges are expected to award." ${ }^{100}$ Joni Hersch and W. Kip Viscusi, using the same data as Eisenberg et al., reached a strikingly different conclusion:

93. See George L. Priest \& Benjamin Klein, The Selection of Disputes for Litigation, 13 J. LEGAL StUd. 1 (1984); Joel Waldfogel, Selection of Cases for Trial, in 3 THE NEW PALGRAVE DictionaRy OF ECONOMICS AND THE LAW 419 (Peter Newman ed., 1998).

94. Kevin M. Clermont \& Theodore Eisenberg, Trial By Jury or Judge: Transcending Empiricism, 77 CORNELL L. REV. 1124, 1137-38 (1992).

95. Id. at 1126. For an alternative interpretation of their results, see Richard A. Posner, An Economic Approach to the Law of Evidence, 51 STAN. L. REV. 1477, 1501 (1999).

96. Eric Helland \& Alexander Tabarrok, Runaway Judges? Selection Effects and the Jury, 16 J.L. \& ECON. ORG. 306, 330 (2000).

97. Id.

98. Theodore Eisenberg et al., Juries, Judges, and Punitive Damages: An Empirical Study, 87 CORNELL L. REV. 743 (2002).

99. Id. at 779 .

100. $I d$. 
What we found based on a careful statistical analysis was that these data are quite consistent with there being greater restraint by judges. Our statistical analysis of the level of punitive damages awards for all cases, including those with compensatory damages but no punitive awards, showed that juries award higher levels of punitive damages. If one considers the components of this effect, juries also differ from judges. Juries have a higher probability of awarding punitive damages. Moreover, juries are especially likely to make a large punitive damages award conditional on there being a punitive damages award. Thus, juries are more prone to generate large awards than are judges. ${ }^{101}$

The differing results, according to Hersch and Viscusi, were the result of the two studies treating trials from one county differently and Eisenberg et al.'s use of two jury variables highly correlated with one another. ${ }^{102}$

A final study by Eisenberg (with different coauthors) focused directly on cognitive differences between judges and juries and found more coherence in punitive damages awards than behavioral theories would predict. ${ }^{103}$ The cognitive problem considered was one of "scaling without a modulus": the difficulty of translating moral judgments about behavior into a quantitative damages award. ${ }^{104}$ The authors found (using the same state-court jury sample as above) ${ }^{105}$ some incoherence in punitive damages awards of the sort predicted by the theory, but far less than experimental studies would indicate. ${ }^{106}$ They concluded that "[f]orces seem to be at work that already promote coherence," so structural changes suggested by some commentators (such as shifting punitive damages decisionmaking from juries to judges ${ }^{107}$ may be unnecessary. ${ }^{108}$

\section{Conclusions}

The existing evidence on the effect of cognitive illusions on arbitral decisionmaking is slight. Drawing from studies of judicial decisionmaking (on the assumption that arbitrators are more like judges than jurors), however, provides

101. Joni HersCh \& W. Kip VisCusi, Punitive DAMAgES: How Judges AND JuRIES PERForm 36 (Harvard-John M. Olin Discussion Paper No. 362, May 2002).

102. Id. at 31-34 (explaining that the differing results were due to the disparate treatment of Harris County, Texas, and Eisenberg et al.'s use of "both a jury indicator variable as well as the interaction of jury trial with compensatory damages," which served "to induce multicollinearity").

103. Theodore Eisenberg et al., Reconciling Experimental Incoherence with Real-World Coherence in Punitive Damages, 54 STAN. L. REV. 1239 (2002).

104. See Cass R. Sunstein et al., Assessing Punitive Damages (with Notes on Cognition and Valuation in Law), 107 YALE L.J. 2071 (1998); Sunstein et al., supra note 40, at 1155; Sunstein, supra note 5, at 142-44. According to Sunstein et al., one consequence is that while decisions may be "sensible and coherent" within a category of cases, they become incoherent when compared across categories of cases. Sunstein et al., supra note 40, at 1170. Decisionmakers who see multiple categories of cases (for example, judges and perhaps arbitrators) thus may make better decisions than decisionmakers who see only one case (for example, juries). $I d$.

105. See supra text accompanying notes 98-102.

106. Eisenberg et al. tested the following predictions they derived from the theory: (1) "the relation between punitive and compensatory awards will not meaningfully vary across case categories in actual jury cases"; and (2) "“case categories' influence should be greater in judge-tried cases than in jury-tried cases." Eisenberg et al., supra note 103, at 1248. They found "modest support" for these predictions in the data. Id.

107. See supra text accompanying note 40 .

108. Eisenberg et al., supra note 103, at 1259. 
further insights. The experimental studies of judges and jurors, while certainly not conclusive, find that judges are less subject to some cognitive biases and heuristics than jurors and equally, but no more, subject to others. Although studies of litigation outcomes suggest that the effect of cognitive illusions is less than might be expected, some differences in outcome seem to persist. As such, the studies suggest (albeit tentatively) that arbitral decisionmaking, to the extent it is like judicial decisionmaking, is less subject than jury decisionmaking to some cognitive illusions, and equally subject to others. ${ }^{109}$

IV

\section{STRUCTURAL DIFFERENCES BETWEEN JURY TRIALS AND ARBITRATION}

Part III suggested a tentative conclusion about the effects of cognitive biases and heuristics on arbitral decisionmaking, based largely (although not exclusively) on experimental studies: arbitrators may be less subject to at least some cognitive illusions than are jurors. This Part examines various structural differences between jury trials and arbitration proceedings and considers whether the differences are likely to increase or decrease the effects of cognitive illusions.

\section{A. Group Versus Individual Decisionmaking}

A key difference between juries and arbitrators is in the decisionmaking dynamic. Arbitrators decide either alone or in panels of three ${ }^{110}$ whereas juries decide in groups varying from six to twelve members. ${ }^{111}$ Most experimental studies of jury behavior ignore the possible effects of group deliberations and focus on the decisionmaking of individual jurors. ${ }^{112}$ Others select "synthetic

109. If arbitral decisionmaking bears at least some relationship to decisionmaking by judges, one might ask why businesses use arbitration clauses rather than jury-trial waivers in their standard-form contracts. There are several possible explanations. First, arbitral decisionmaking may be less subject to biases and heuristics than judicial decisionmaking, perhaps because of market competition or the subject-matter expertise of arbitrators. Cf. Jeffrey J. Rachlinski, Heuristics and Biases in the Courts: Ignorance or Adaptation?, 79 OR. L. REV. 61, 64 (2000) ("Judges surely have some incentives to make good law and avoid illusions of judgment, but they lack the incentives that other institutions face."); Posner, supra note 95, at 1494 ("The literature on these illusions provides some basis for thinking that market settings tend to dispel or at least reduce them, but none for thinking that government processes have similar effects."). Second, businesses might be indifferent between judges and arbitrators (or perhaps even prefer judges), but use arbitration clauses because courts are unwilling to enforce predispute waivers of the right to jury trial. See Sternlight, Mandatory Binding Arbitration, supra note 11, at 677-95; Stephen J. Ware, Arbitration Clauses, Jury-Waiver Clauses, and Other Contractual Waivers of Constitutional Rights, 67 LAW \& CONTEMP. PROBS. 167, 200-04 (Winter/Spring 2004) (describing court decisions requiring knowing consent to enforce provisions purporting to waiver a party's jury-trial rights). Third, other factors, such as the availability of class relief and confidentiality, may-and certainly do, to some extent-lead businesses to prefer arbitration over bench trials.

110. E.g., Am. Arbitration Ass'n, Commercial Arbitration Rules, Rule R-15 (effective July 1, 2003) [hereinafter AAA COMMERCIAL ARBITRATION RULES].

111. Bureau of Justice Statistics, U.S. DeP'T of Justice, State Court Organization 278, tbl. 42 (1998). For an overview of research on the effects of jury size, see SWARD, supra note 12, at 215-18.

112. See David R. Shaffer \& Shannon R. Wheatman, Does Personality Influence Reactions to Judicial Instructions? Some Preliminary Findings and Possible Implications, 6 PSYCHOL. PUB. POL'Y \& L. 655 , 657 (2000) ("[P] erhaps the greatest limitation of mock-trial simulations is that the vast majority of them 
juries" that combine individual respondents into jury panels and then use the median response as the verdict of the synthetic jury. ${ }^{113}$ While such an approach tends to mitigate the effect of outlying responses, it does not take into account the dynamics of group deliberations and any effect they may have on actual verdicts.

If group decisions differ from individual decisions, these differences in decisionmaking dynamics could be an important structural differences between jury trials and arbitration. One possibility is that group deliberations dampen the effect of cognitive illusions on jury verdicts because discussions within the group improve the accuracy of the group's decision. Because arbitrators decide alone or in small groups, there is no, or at least less, opportunity for group deliberations to reduce the effect of cognitive illusions on arbitration awards. On the other hand, group polarization may result in group decisions that are more extreme than the median of the individual members' views. ${ }^{114}$ If so, jury verdicts may be more extreme than predicted by experimental studies, while arbitral decisionmaking would be much less affected.

The empirical evidence on the point is mixed. ${ }^{115}$ At least some studies, however, have found that deliberations can exacerbate, rather than lessen, cognitive biases in decisionmaking. ${ }^{116}$ For example, in an experimental study of punitive damages awards, David Schkade and others found that jury deliberations tended to result in more extreme verdicts: when individual jurors rated behav-

attempt to draw inferences from decisions rendered by nondeliberating mock jurors rather than deliberating mock juries.").

113. E.g., VIDMAR, supra note 67, at 226-28; Viscusi, supra note 83, at 124.

114. See generally Cass R. Sunstein, Deliberative Trouble? Why Groups Go to Extremes, 110 YALE L.J. 71, 85-97 (2000) (discussing group polarization).

115. Norbert L. Kerr et al., Bias in Judgment: Comparing Individuals and Groups, 103 PSYCHOL. REV. 687, 713 (1996); Norbert L. Kerr et al., Bias in Jurors vs. Bias in Juries: New Evidence from the SDS Perspective, 80 ORG'L BEHAV. \& HUM. DECISION PROCESSES 70, 82 (1999) ("For the jury, our findings confirm what is evident in the empirical record-that there is probably no general answer to the question 'which is more biased, jurors or juries?' The answer to this question must be 'it depends."'); see, e.g., Dagmar Stahlberg \& Frank Eller, We Knew It All Along: Hindsight Bias in Groups, 63 ORG'L BEHAV. \& HUM. DECISION PROCESSES 46, 56 (1995) (finding that "groups are as prone to hindsight bias as individuals when making hypothetical predictions," but rejecting the suggestion of greater hindsight bias in groups). For studies finding benefits of jury deliberations, see, for example, Kamala London \& Narina Nunez, The Effect of Jury Deliberations on Jurors' Propensity to Disregard Inadmissible Evidence, $85 \mathrm{~J}$. APPLIED PSYCHOL. 932, 937 (2000) ("[S]tudies find that individuals are biased when exposed to inadmissible evidence. However, the results [here], as well as results from other research, suggest that jury deliberations may somehow moderate the effect of biasing factors."); James H. Davis et al., Effects of Group Size and Procedural Influence on Consensual Judgments of Quantity: The Example of Damage Awards and Mock Civil Juries, 73 J. PeRsonality \& SOC. PSYCHOL. 703, 714 (1997) (reporting the "surprising" result that "groups awarded less than preferred by parallel individuals working alone, although this difference is only marginally significant"). See generally MiCHAEL J. SAKS, SMALL-GROUP DECISION MAKING AND COMPLEX INFORMATION TASKS 3 (1981) ("The legal fact-finding task, especially in complex cases, seems to be of the type in which, ceteris paribus, large heterogeneous groups perform better than individuals.").

116. E.g., Shari Seidman Diamond \& Jonathan D. Casper, Blindfolding the Jury to Verdict Consequences: Damages, Experts, and the Civil Jury, 26 LAW \& SOC'Y REv. 513, 553-57 (1992); Martin F. Kaplan \& Charles E. Miller, Group Decision Making and Normative Versus Informational Influence: Effects of Type of Issue and Assigned Decision Rule, 53 J. Personality \& SOC. PsYCHOL. 306, 311 (1987). 
ior as worthy of strong punishment, deliberation increased the overall jury rating; when individual jurors rated behavior as worthy only of weak punishment, deliberation tended to decrease the overall jury rating. ${ }^{117}$ As applied to punitive damages, when individual jurors favored large awards of punitive damages, deliberations increased the amount awarded by the jury. Indeed, Schkade et al. reported that $27 \%$ of mock juries voting to award punitive damages awarded amounts as great or greater than the highest individual award before deliberations. ${ }^{118}$ Similar effects have been identified in studies of decisionmaking by federal appellate courts. ${ }^{119}$

Thus, at least some evidence indicates that group deliberations do not reduce and may actually heighten the effects of cognitive illusions on decisionmaking. Other evidence suggests that deliberations might moderate such effects. ${ }^{120}$ The bottom line is uncertain.

\section{B. Markets and Incentives}

Jurors are selected randomly and paid a small, fixed fee. ${ }^{121}$ Their "financial incentive to conduct a careful sifting of the evidence is nil." 122 Arbitrators, by comparison, get paid only if selected to serve, and must compete with other arbitrators to be selected. This market competition gives arbitrators different incentives from juries, which may improve the quality of their decisionmaking by inducing greater care. ${ }^{123}$

The broader question is whether these sorts of market forces are sufficient to mitigate the effects of heuristics and cognitive biases. Richard Posner writes that "[t]he literature on [cognitive] illusions provides some basis for thinking that market settings tend to dispel or at least reduce them." ${ }^{124}$ Selection effects

117. David Schkade et al., Deliberating About Dollars: The Severity Shift, 100 Colum. L. REV. 1139, $1140(2000)$.

118. Id. at $1155-56$ (finding $10 \%$ were higher than the highest individual award and $17 \%$ equal to the highest individual award). They also found greater variability in awards by deliberating juries, and concluded: "This finding suggests, though it certainly does not prove, the possibility that juries will produce more variability in awards than judges (a suggestion supported by the possibility that judicial experience with a wider range of cases will introduce the equivalent of a 'modulus' by which to discipline dollar awards)." Id. at 1148 n.43.

119. See Frank B. Cross \& Emerson H. Tiller, Judicial Partisanship and Obedience to Legal Doctrine: Whistleblowing on the Federal Courts of Appeals, 107 YALE L.J. 2155 (1998); Richard L. Revesz, Environmental Regulation, Ideology, and the D.C. Circuit, 83 VA. L. REV. 1717, 1755 (1997).

120. See supra note 115.

121. BuREAU OF JUSTiCE STATISTICS, supra note 111, at 269, tbl. 40.

122. Posner, supra note 95 , at 1497 . This is not to say that juries do not take their responsibilities seriously, merely that they have no financial incentive to do so.

123. See, e.g., Gordon TUllock, TRIALs On TRIAL 127-33 (1980); Robert D. Cooter, The Objectives of Private and Public Judges, 41 PUB. CHOICE 107, 107 (1983); Robert D. Cooter \& Daniel L. Rubinfeld, Trial Courts: An Economic Perspective, 24 LAW \& SOC'Y REV. 533, 545 (1990); Christopher R. Drahozal, Judicial Incentives and the Appeals Process, 51 SMU L. REV. 469, 502 (1998); Stephen Walt, Decision by Division: The Contractarian Structure of Commercial Arbitration, 51 RUTGERS L. REV. 369, 411 (1999).

124. Posner, supra note 95, at 1494; see also Sunstein, supra note 5, at 150 ("In some circumstances, market forces are indeed strong enough to make behavioral economics irrelevant for predictive purposes. Then the question becomes whether it is possible to identify those circumstances. This is a large question, and we lack authoritative answers."). For a pair of recent studies, see John A. List, Does Market Experi- 
that reduce cognitive illusions are more likely in market settings ${ }^{125}$ and the greater amount at stake may lead to less biased results than experimental studies find, although the evidence on this point is uncertain. ${ }^{126}$ Other commentators, however, are skeptical that the market has sufficient corrective effect. ${ }^{127}$

Moreover, competition among arbitrators also gives rise to the possibility of "repeat player" bias, in which arbitrators have an incentive to favor parties who are more likely to provide future business. ${ }^{128}$ To date, however, the evidence is inconclusive on whether such bias exists. ${ }^{129}$

Lisa Bingham found a "repeat player effect" in a sample of 270 AAA employment arbitration awards issued in 1993 and 1994. ${ }^{130}$ Employees were awarded some recovery in $63 \%$ of all awards, but in only $16 \%$ of awards against repeat player employers-which Bingham defined as employers who were parties to more than one award in the sample. Employees recovered $48 \%$ of their demands against non-repeat player employers, but only $11 \%$ of their demands against repeat player employers. ${ }^{131}$ Bingham made clear that there were several possible explanations for these results, including that there were "systematic differences in the merits of these cases, in that employees in repeat player cases

ence Eliminate Market Anomalies?, 118 Q.J. ECON. 41, 70 (2003) ("I find strong evidence that individual behavior converges to the neoclassical prediction as trading experience intensifies."); JOHN A. LIST, NEOCLASSICAL THEORY VERSUS PROSPECT THEORY: EVIDENCE FROM THE MARKETPLACE 3 (Nat'l Bureau of Econ. Research, Working Paper No. 9736, 2003), available at http://www.nber.org/papers/w9736 ("Overall, the data pattern observed suggests that the learning process at work is one where the psychological effects at the heart of prospect theory are gradually attenuated: experienced agents are more willing to part with their endowments than lesser-experienced agents.”).

125. See supra text accompanying notes 41-42.

126. See, e.g., Vernon L. Smith \& James M. Walker, Monetary Rewards and Decision Cost in Experimental Economics, 31 ECON. INQUIRY 245, 259 (1993) ("A survey of experimental papers which report data on the comparative effects of subject monetary awards (including no rewards) shows a tendency for the error variance of the observations around the predicted optimal level to decline with increased monetary reward."); Dan N. Stone \& David A. Ziebart, A Model of Financial Incentive Effects in Decision Making, 61 ORG'L BEHAV. \& HUM. DECISION PROCESSES 250, 259 (1995) (“[R]esults support the contention that financial incentives are no panacea for eliminating decision biases. Instead, incentives appear to increase the extent of attention given to a task, but also to increase potentially distracting emotions."). See generally Colin F. Camerer \& Robin M. Hogarth, The Effects of Financial Incentives in Experiments: A Review and Capital-Labor-Production Framework, 19 J. RISK \& UNCERTAINTY 7, 8 (1999) ("The studies show the effects of incentives are mixed and complicated."); Mitchell, Equal Incompetence, supra note 5, at 71-80 ("Sometimes decisions with material consequences are the same as decisions without material consequences; sometimes they are different.").

127. E.g., Langevoort, supra note 5, at 1523 .

128. E.g., Rau, supra note 48, at 521-29; Schwartz, supra note 3, at 60-61; Sternlight, supra note 1, at 685. See generally Marc Galanter, Why the "Haves" Come Out Ahead: Speculations on the Limits of Legal Change, 9 LAW \& SOC'Y REV. 95 (1974). As Gordon Tullock has explained, however, the incentive of arbitrators to please repeat players does not necessarily mean that they will rule in favor of the repeat players. TULLOCK, supra note 123, at 127-28 ("[A] bias toward the [repeat-player] retailer might be the arbitrator's profit-maximizing course of action. It might not, however, because the retailer might be interested in his general reputation and want an arbitrator who was either impartial or, for that matter, actually pro-customer.").

129. Walt, supra note 123 , at 418.

130. Bingham, The Repeat Player Effect, supra note 46, at 189-90.

131. Id. at 213 . 
may have weaker legal claims, while employees in the non-repeat player cases may have stronger legal claims. ${ }^{" 132}$

In a follow-up study based on 203 AAA employment arbitration awards from 1993 to 1995, Bingham obtained similar results. ${ }^{133}$ She concluded, however, that "these patterns largely correspond with differences in the nature of the basis for arbitration." According to Bingham, "[r]epeat player employers get to arbitration based on an implied contract stemming from a personnel manual or employee handbook," cases in which the employee "may have a substantively weaker legal claim." ${ }^{134}$ In short, the repeat player effect Bingham has identified seems to have had more to do with the strength of the repeat player employer's claim (and, perhaps, ability to screen cases) than with the incentives facing the arbitrator. In a subsequent study, Bingham and Simon Sarraf compared outcomes before and after the Employment Due Process Protocol ${ }_{1}^{135}$ and found that "employers arbitrating pursuant to an adhesive personnel handbook arbitration clause are less successful in employment arbitration after the Protocol than before." "136 They concluded that "[s]elf-regulation through the Due Process Protocol is making a difference in the outcomes of employment arbitration." ${ }^{137}$

Thus, the available empirical evidence on the relationship between markets and arbitral decisionmaking is inconclusive. While there is reason to believe that market forces may reduce the effect of cognitive illusions on arbitral decisionmaking, the results of existing studies are far from conclusive. Conversely, while arbitrators may have an incentive to favor repeat players in their awards, the limited evidence of a repeat player effect seems to be due to case selection by the parties and not bias on the part of the arbitrators. Overall, then, no definitive answer is possible.

\section{Other Differences}

There are a variety of other structural differences between arbitration proceedings and jury trials that could correct for, or exacerbate, the effect of cognitive illusions on legal decisionmaking. The following are a sample.

132. $I d$.

133. Bingham, Unequal Bargaining Power, supra note 46, at 38-39; see also Bingham, On Repeat Players, supra note 46 , at 223.

134. Bingham, Unequal Bargaining Power, supra note 46, at 39-40.

135. TASk Force on Alternative Dispute Resolution in EMPloyment, A Due Process Protocol For MEdiation and ARbitration of Statutory Disputes ARISING OUT OF THE EMPLOYMENT RELATIONSHIP (1995), available at $\mathrm{http}: / / \mathrm{www}$.adr.org/index2.1.jsp?JSPssid=15717\&JSP $\mathrm{src}=$ upload/LIVESITE/focusArea/employment/protocol.html. The Protocol establishes minimum standards of procedural fairness for employment arbitration proceedings. The American Arbitration Association was involved in the drafting of the Protocol. The AAA states that its employment arbitration rules comply with the Protocol and that it may refuse to administer arbitration proceedings under any program that "substantially and materially" departs from the Protocol. AM. ARBITRATION Ass'N, NATIONAL RULES FOR THE RESOLUTION OF EMPLOYMENT DISPUTES (effective Nov. 1, 2002).

136. Bingham \& Sarraf, supra note 46; see also Bingham, Self-Determination, supra note 46, at 873.

137. Bingham \& Sarraf, supra note 46. 


\section{Fees}

To file a lawsuit, a plaintiff merely pays a small filing fee (in addition to paying his or her own lawyer, on a contingency basis or otherwise). ${ }^{138}$ No other charge is made by the public court system; judges' salaries and other administrative costs are paid by the government. By comparison, a claimant filing a demand for arbitration pays fees both to any arbitration institution providing administrative services and to the arbitrator or arbitrators resolving the dispute. ${ }^{139}$ As a general matter, the fees are graduated, increasing as the amount sought by the claimant increases.

The policy discussions ${ }^{140}$ and court cases ${ }^{141}$ dealing with arbitration fees consider the extent to which such fees might preclude individuals from asserting claims in arbitration. The focus here, however, is on a different consequence of arbitration fees: their effect on party behavior in the arbitration proceeding. As discussed above, a number of experimental studies have found that the amounts claimed by plaintiffs have a strong anchoring effect on jury verdicts. ${ }^{142}$ In court, the plaintiff has little financial incentive to moderate damages claims. In arbitration, however, a claimant has a significant financial incentive to be realistic about damages claims because of the graduated fees charged by most arbitration institutions. ${ }^{143}$ Claimants who ask for more have to pay more, which may counteract to some degree any bias resulting from anchoring on the amount sought. ${ }^{144}$

\section{Rules of Evidence}

Detailed rules govern the admissibility and presentation of evidence in court. By contrast, formal rules of evidence ordinarily do not apply in arbitration. ${ }^{145}$ Further, despite having the power to exclude irrelevant evidence,${ }^{146}$ arbi-

138. E.g., Public Citizen's CONGRESS WATCh, The COSTS OF ARBITRATION 43 (2002), available at http://www.publiccitizen.org/documents/ACF110A.pdf.

139. 1 IAN R. MACNEIL ET AL., FEDERAL ARbITRATION LAW § 3.2.2.2, at 3:13 (1999).

140. E.g., Public Citizen's Congress WATCH, supra note 138, at 42; Paul D. Carrington \& Paul H. Haagen, Contract and Jurisdiction, 1996 SuP. CT. REV. 331, 384-85; Schwartz, supra note 3, at 61.

141. E.g., Green Tree Fin. Corp.-Ala. v. Randolph, 531 U.S. 79 (2000); Morrison v. Circuit City Stores, Inc., 317 F.3d 646 (6th Cir. 2003); Cole v. Burns Int'l Sec. Servs., 105 F.3d 1465 (D.C. Cir. 1997).

142. See supra Part II.A.2.

143. The fee structure in arbitration provides an alternative explanation for Maltby's findings, see supra text accompanying notes 61-63, that arbitration claimants recover a higher percentage of their demands than do plaintiffs in federal court. See Christopher R. DraHozal, COMMERCIAL ARBITRATION: CASES AND PROBLEMS 7 (2002) ("Given that the fees parties pay in arbitration are based on the amount demanded, [Maltby's] numbers may reflect no more than the fact that parties in arbitration have a strong incentive to be more realistic about their initial demands than parties in court.").

144. Of course, arbitration fees may be higher or lower than necessary to result in an optimal damage claim by the claimant.

145. See, e.g., AAA COMmercial ARbitration RULes, supra note 110, Rule R-31(a); NATIONAL ARbitration Forum CODE OF PROCEDURE, Rule 35(C) (July 1, 2003); JAMS EMPLOYMENT ARbitration RUles AND Procedures, Rule 20(d) (revised Apr. 2003) [hereinafter JAMS EMPLOYMENT RULES]. Parties can and sometimes do contract for rules of evidence to apply in arbitration proceedings, but such contract provisions are rare. See Drahozal, supra note 8, at 731 (reporting that three clauses in a sample of thirty-four arbitration clauses in franchise agreements provided for the Federal Rules of Evidence to govern in arbitration proceedings). 
trators have a "well documented" tendency to "let it all in." 147 The gatekeeping function of the trial judge over the admission of evidence "is one way of combating cognitive illusions." ${ }^{148}$ For example, Federal Rule of Evidence 407, which provides that evidence of subsequent remedial measures is not admissible to prove negligence or other wrongful conduct, ${ }^{149}$ "reveals a good understanding of ... hindsight bias and the judicial ability to respond to it." ${ }^{150}$ The absence of rules of evidence in arbitration may increase the relative susceptibility of arbitral decisionmaking to hindsight bias. ${ }^{151}$

\section{Appellate Review}

Court rules provide for some degree of substantive oversight of jury verdicts, such as by permitting judges to grant a new trial or a judgment notwithstanding the verdict. ${ }^{152}$ Courts exercise especially stringent scrutiny over awards of punitive damages. ${ }^{153}$ Indeed, studies show that a significant percentage of punitive damages awards by juries are modified or set aside,$^{154}$ suggesting that courts take their supervisory role seriously. Both jury verdicts and bench-trial verdicts are subject to review by appellate courts, with factual findings subject to some degree of deference and legal issues reviewable de novo. The availability of appellate review may correct errors resulting from cognitive biases, ${ }^{155}$ give judges the incentive to avoid errors in the first place ${ }^{156}$ and provide feedback useful in avoiding future errors. ${ }^{157}$ By comparison, only very limited

146. See, e.g., AAA COMmercial ARBitration Rules, supra note 110, Rule R-31(b); JAMS EMPLOYMENT RULES, supra note 145, Rule 20(d).

147. 3 MACNEIL ET AL., supra note $139, \S 35.1 .2 .4$, at 35:9.

148. Posner, supra note 95, at 1494.

149. FED. R. EVID. 407.

150. Rachlinski, supra note 14, at 617-18. Rachlinski argues, however, that as a general matter keeping evidence from the jury "probably cannot cure the hindsight bias" because "[t]o avoid the influence of the bias, the evidence that needs to be suppressed is the very fact that some adverse event led to a lawsuit." Id. at 605 .

151. Cf. Posner, supra note 95, at 1494 ("If judges as well as jurors are prone to make cognitive errors or be overcome by emotion, trial by jury may actually proceed more rationally than trial by judge, since in a bench trial there is no gatekeeper protecting the trier of fact from confusing or excessively prejudicial evidence.").

152. See, e.g., FED. R. CIV. P. 50, 59; see also SWARD, supra note 12, at 271-99.

153. E.g., State Farm Mut. Auto. Ins. Co. v. Campbell, 538 U.S. 408 (2003); BMW of N. Am., Inc. v. Gore, 517 U.S. 559 (1986).

154. E.g., W. KIP VISCUSI, REFORMING PRODUCTS LIABILITY 94 (1991) (concluding that "plaintiffs received only .. . 29\% of the original punitive award" due to reduction on appeal or settlement after verdict); Neil Vidmar et al., Jury Awards for Medical Malpractice and Post-verdict Adjustment of Those Awards, 48 DEPAUL L. REV. 265 (1998) (finding many outlier compensatory damage verdicts reduced after verdict).

155. Steven Shavell, The Appeals Process as a Means of Error Correction, 24 J. LEGAL Stud. 379 (1995).

156. Drahozal, supra note 123, at 492.

157. David A. Schkade, Erratic by Design: A Task Analysis of Punitive Damages Assessment, 39 HARV. J. ON LEGIS. 121, 130 (2002) ("Jurors get neither rewards nor feedback based on their decisions.") (italics omitted). 
appellate review is available for arbitration awards. ${ }^{158}$ Courts will vacate awards only on narrow procedural grounds ${ }^{159}$ or for manifest disregard of the law. ${ }^{160}$ Thus, in arbitration there is far less opportunity to avoid any errors resulting from heuristics or cognitive biases through appellate review than there is in court. ${ }^{161}$

\section{$\mathrm{V}$ \\ CONCLUSION}

Businesses cite arbitration as a way to avoid aberrant jury verdicts, implicitly if not explicitly assuming that arbitrators make "better" decisions than juries. By contrast, consumer advocates criticize arbitration as a way for businesses to avoid paying damages to deserving claimants, effectively assuming that juries make better decisions than arbitrators. These conflicting perspectives pose an important question in the debate over predispute arbitration clauses in consumer contracts: How do decisions by arbitrators compare to decisions by juries?

From a behavioral perspective, arbitral decisionmaking appears to be less subject to cognitive illusions than decisionmaking by juries. This is not an across-the-board conclusion about the superiority of arbitral decisionmaking, but rather a tentative conclusion about the effect of heuristics and cognitive biases on two modes of legal decisionmaking. It is based largely on experimental studies of decisionmaking by judges, and it recognizes that the comparison between judges and arbitrators is not perfect and that drawing real-world conclusions from experimental results is difficult. If arbitral decisionmaking in fact proves to be less subject to cognitive illusions than jury decisionmaking, it would provide some evidence that arbitrators may make "better," or at least no worse, decisions than juries.

The most obvious conclusion to be drawn from this analysis, however, is that more research is needed on how cognitive illusions affect arbitral decisionmaking. Commentators have already called for studies on the psychology of dispute resolution in the international arbitration context. ${ }^{162}$ Neil Vidmar and Lisa

158. Parties may, however, provide by contract for an appellate arbitral tribunal. See, e.g., JAMS EMPLOYMENT RULES, supra note 145, Rule 30 \& Optional Arbitration Appeal Procedure.

159. See, e.g., 9 U.S.C. $§ 10$ (2000 \& Supp. 2003). See generally 4 MACNEIL ET AL., supra note 139, § 40 (discussing the grounds for vacating arbitration awards).

160. See Wilko v. Swan, 346 U.S. 427, 436-37 (1953) ("[T]he interpretations of the law by the arbitrators in contrast to manifest disregard are not subject, in the federal courts, to judicial review for error in interpretation.")

161. For an incentives-based explanation for the lack of an appeals process in commercial arbitration, see Drahozal, supra note 123, at 502.

162. See Shari Seidman Diamond, The Psychological Aspects of Dispute Resolution: Issues for International Arbitration, in INTERNATIONAL COMMERCIAL ARBITRATION: IMPORTANT CONTEMPORARY QUESTIONS 327, 342 (Albert Jan van den Berg ed., 2003) (suggesting a research agenda that would "systematically observe ... and analyze ... actual behavior and the decision-making process" in international arbitration, comparable to recent study of jury deliberations); Christopher R. Drahozal, Of Rabbits and Rhinoceri: A Survey of Empirical Research on International Commercial Arbitration, 20 J. INT'L ARB. 23, 32-33 (2003). 
Bingham have both used arbitrators as experimental subjects while examining other issues. ${ }^{163}$ Studies of cognitive illusions in the context of consumer arbitration would be of great interest and practical importance as well.

Experimental studies have the clear benefit of holding constant the facts facing the decisionmaker. Problems would need to be developed (preferably with significant detail and context provided to the decisionmaker) to test for the effect of various cognitive illusions, such as hindsight bias, anchoring, the representativeness heuristic, and extremeness aversion. Conferences attended by arbitrators would be an obvious place to administer the problems. They also could be administered by mail, although the response rate almost certainly would be lower. To facilitate comparisons, the problems should be administered to mock jurors as well. Such experimental studies would provide a good starting point for the behavioral analysis of arbitral decisionmaking, as well as contributing to a comparison of decisionmaking by arbitrators and juries. ${ }^{164}$

163. Lisa B. Bingham \& Debra J. Mesch, Decision Making in Employment and Labor Arbitration, 39 INDUS. REL. 671 (2000) (reporting the results of an experimental study comparing labor and employment arbitrators); see Vidmar \& Rice, supra note 42, at 890-91.

164. Studies of outcomes in arbitration proceedings, testing for the effect of cognitive illusions, likewise would be of interest, but would be far more difficult to design. Problems of case selection and ensuring comparable facts make studies of arbitration outcomes_-particularly any attempts to compare arbitration awards to jury verdicts-highly problematic. See, e.g., Stephen J. Ware, The Effects of Gilmer: Empirical and Other Approaches to the Study of Employment Arbitration, 16 OHIO ST. J. ON DISP. RESOL. 735,757 (2001) ("Empirical studies are vulnerable to the possibility that the studied cases going to arbitration are systematically different from the studied cases going to litigation. This will remain true as long as the law allows contracts to determine whether or not a case goes to arbitration."). 